\title{
Cardiac Complications in Pregnancy: A Systematic Review and Meta-Analysis of Diagnostic Accuracy of BNP and N-Terminal Pro-BNP
}

\author{
Mahboobeh Sheikh · Pouya Ostadrahimi · Morteza Salarzaei • \\ Fateme Parooie
}

Received: May 4, 2021 / Accepted: June 12, 2021 / Published online: July 2, 2021

(C) The Author(s) 2021

\begin{abstract}
Introduction: Serum brain-type natriuretic peptide (BNP) levels may be involved in detecting the breakdown of defense mechanisms in pregnant women. BNP and N-terminal pro-BNP (NT-proBNP) levels can be used in emergency settings as a biomarker to rule out or confirm cardiac complications. The present study was conducted as an attempt to evaluate the performance of BNP and NT-proBNP as diagnostic tools for cardiac complications, including heart failure and pre-eclampsia, in pregnant and recently-delivered women.

Methods: This meta-analysis was performed according to the Preferred Reporting Items for Systematic Reviews and Meta-Analyses (PRISMA) guidelines. To extract the data, articles meeting the inclusion criteria were directly reviewed by two of the authors. Disputes were resolved through discussion with all authors before data mining. In cases of unresolved disagreement, a third reviewer was consulted to achieve consensus. A quantitative analysis of the total bias of publications was performed
\end{abstract}

\section{Sheikh}

Department of Cardiology, Faculty of Medicine, Zabol University of Medical Sciences, Zabol, Iran

P. Ostadrahimi $(\bowtie) \cdot$ M. Salarzaei · F. Parooie Faculty of Medicine, Zabol University of Medical Sciences, Zabol, Iran

e-mail: thn.search@gmail.com using Stata software version 14.0, using funnel plots and Deek's test.

Results: Overall, 13 unique studies were included in this review. The pooled sensitivity, specificity and positive and negative predictive values for diagnosing cardiac complications in pregnant women when BNP level was $\leq 100 \mathrm{ng} /$ $\mathrm{L}$, were determined to be $95,62,71$ and $91 \%$, respectively. The corresponding measures when the BNP levels were 100-500 ng/L were calculated to be $98,92,97$ and $92 \%$, respectively. The pooled sensitivity, specificity and positive and negative predictive values for diagnosing cardiac complications in pregnant women using NT-proBNP were 78, 74, 20.5 and 97\%, respectively.

Conclusion: Our results suggest that both BNP and NT-proBNP levels can be used as diagnostic tools among pregnant and newly-delivered women to diagnose cardiac complications, including heart failure and pre-eclampsia. While BNP showed a relatively better diagnostic accuracy compared to NT-proBNP, it must be noted that the number of studies evaluating NTproBNP included in this meta-analysis was low and the studies were inconsistent in terms of cutoff value. Further studies are required to confirm the prospective use of BNP and NT-pro BNP in assessing common symptoms that indicate cardiac complications during labor. Moreover, the clinical use of the NT-proBNP test in this field requires further study. 
Keywords: Brain-type natriuretic peptide; Nterminal pro-BNP; Pregnancy; Cardiac complications

\section{Key Summary Points}

Serum brain-type natriuretic peptide (BNP) and N-terminal pro-BNP (NTproBNP) levels can be used as diagnostic tools to diagnose cardiac complications in pregnant and newly-delivered women.

There is a significant correlation between high levels of NT-proBNP and the devlopment of pre-eclampsia.

BNP levels of $100-500 \mathrm{ng} / \mathrm{L}$, showed a positive and negative predictive value of 92 and $97 \%$ for diagnosing cardiac complications in pregnancy.

The high sensitivity of BNP (98\%) makes it a good diagnostic method for screening purposes.

\section{DIGITAL FEATURES}

This article is published with digital features, including a summary slide, to facilitate understanding of the article. To view digital features for this article go to https://doi.org/10.6084/ m9.figshare. 14769672

\section{INTRODUCTION}

A number of hemodynamic alterations are associated with pregnancy, including increases in cardiac output, plasma volume and heart rate. Excessive volume loading is often regarded as a major pathogenic mechanism predisposing harmful maternal events during pregnancy. In response to volume overload, B-type natriuretic peptide (BNP) and N-terminal pro-BNP (NTproBNP) levels increase in non-pregnant women; consequently, increased BNP and NTproBNP levels can be used as biomarkers to predict the risk of cardiovascular complications [1-6]. However, despite the identification of clinical predictors of cardiac complications during pregnancy and the use of diagnostic tools such as echocardiography $[7,8]$, current risk stratification is insufficient as it does not include evaluation of maternal heart adequacy and its adaptation during pregnancy. Moreover, as the signs and symptoms of pregnancy can highly mimic the signs of cardiac decompensation, the clinical diagnosis of cardiac disease is complicated still further in pregnant patients; as such, additional tools, such as serum BNP levels, may be useful diagnostic markers to detect the breakdown of defense mechanisms. BNP is a neurohormone that is secreted when ventricular volume and pressure increase [9]. It has a very high sensitivity and specificity for diagnosing cardiac disease that are not influenced by subjective factors. In recent years, studies on the manifestation and role of BNP in heart disease have consistently indicated that it is heavily featured in the appraisals of heart failure [10]. It has been reported that BNP and NTproBNP levels can be used in emergency settings as a biomarker to rule out or confirm heart failure $[12,13]$. However, due to the large number of cardiovascular changes in pregnancy that can affect BNP levels, the use of BNP as a diagnostic marker of heart failure is currently almost entirely limited to the non-pregnant population despite that fact that the level of BNP tends to remain stable throughout all pregnancy trimesters and the postpartum period (4-6 weeks), with the levels of BNP slightly higher in pregnant women and women who have recently delivered (median values ranging from 15.5 to $19 \mathrm{pg} / \mathrm{mL}$ have been reported) $[14,15]$ compared to non-pregnant women (median values of $10 \mathrm{pg} / \mathrm{mL}$ reported) [16, 17]. Increases in BNP and NT-proBNP levels during pregnancy are epecially evident in the setting of pre-eclampsia, with median BNP levels in the range of $21.1-101 \mathrm{pg} / \mathrm{mL}[11,15]$, with a more recent report of $37.1 \mathrm{pg} / \mathrm{mL}$ [17]. Therefore, the main purpose of this study was to assess the performance of BNP and NT-proBNP as diagnostic tools for cardiac complications, including heart failure and pre-eclampsia, in pregnant and recently-delivered women. 


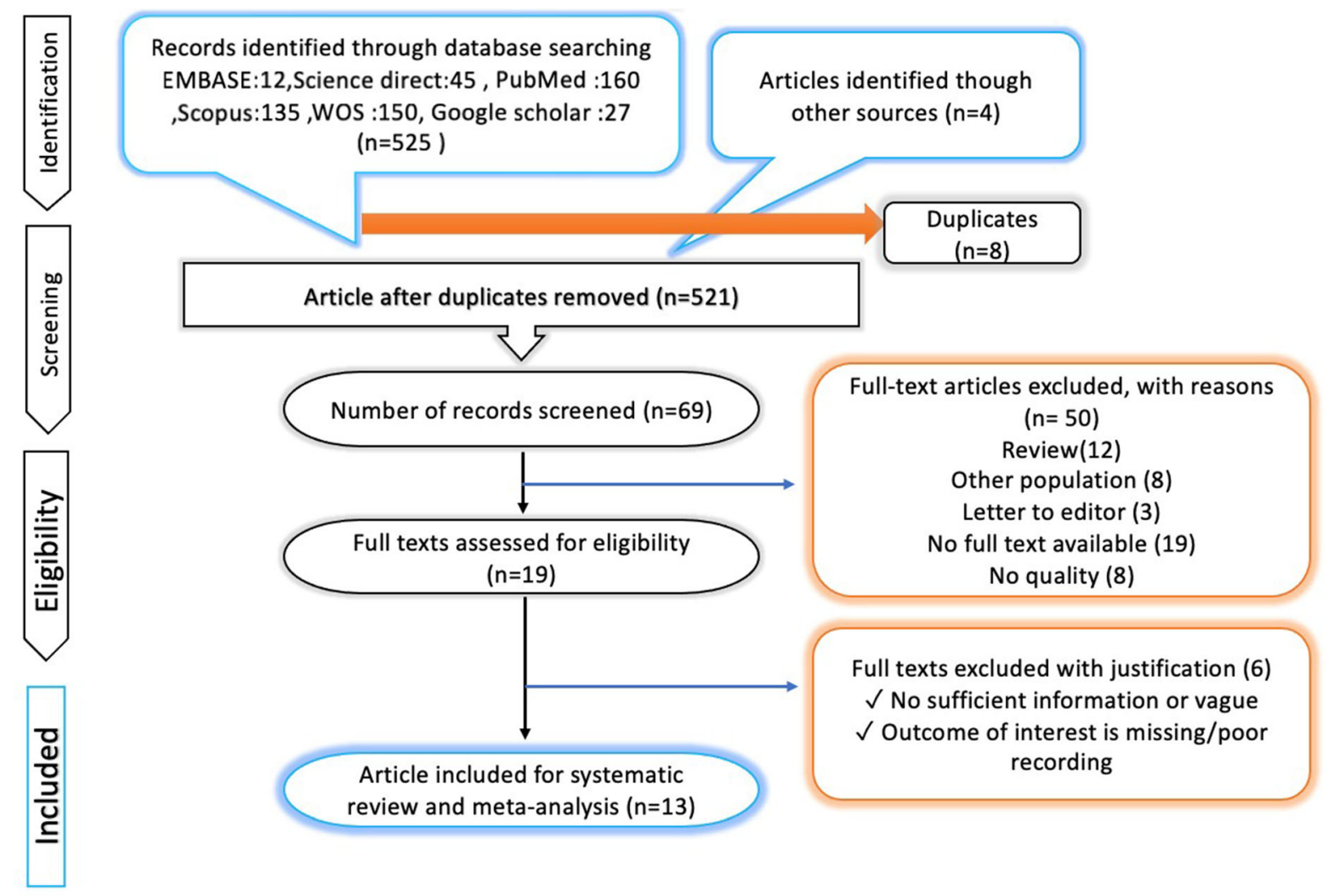

Fig. 1 PRISMA flow diagram

\section{METHODS}

This systematic review and meta-analysis followed the Preferred Reporting Items for Systematic Reviews and Meta-Analyses (PRISMA) guidelines $[18,19]$. This article is based on previously conducted studies and does not contain any new studies with human participants or animals performed by any of the authors.

Search Strategy Different databases, including the Web of Science, PubMed, Medline and ProQuest databases, were searched for relevant articles using the following keywords: "pregnancy," "pre-eclampsia," "heart failure," "heart disease" or "congenital heart disease," "cardiac complications," "BNP" or "B-type natriuretic peptide" or "NT-proBNP". Reference lists of the articles identified to be of interest were also manually searched.

Inclusion/Exclusion Criteria Women who were managed by a team of obstetricians and cardiologists and who had valvular heart disease, congenital heart disease, left ventricular systolic disorder (LVSD) or pulmonary hypertension were eligible for inclusion in this study. Only full-text articles written in English were included. The following studies/articles were excluded: review articles, letters, case studies, expert opinions and conference papers. Also excluded were articles reporting research on animals other than humans and studies including patients with kidney disease, serum creatinine $>1.5 \mathrm{mg} / \mathrm{dL}$, underlying lung disease, twin pregnancies and severe anemia.

Extraction of Data To avoid the inclusion of duplicate data, i.e. studies on the same research population in the same research center, only the largest of the duplicate studies with the longest follow-up time was considered. Also, for studies on different patients at the same research center, only one study was considered. To extract the data, articles meeting the 
Table 1 Characteristics of the included studies

\begin{tabular}{|c|c|c|c|c|c|c|c|c|}
\hline $\begin{array}{l}\text { First } \\
\text { author }\end{array}$ & $\begin{array}{l}\text { Publication } \\
\text { year }\end{array}$ & $\begin{array}{l}\text { Study } \\
\text { period }\end{array}$ & $\begin{array}{l}\text { No. of } \\
\text { patients }\end{array}$ & $\begin{array}{l}\text { Age (in } \\
\text { years) of } \\
\text { patients }( \pm \\
\text { SD) }\end{array}$ & Design & Prevalence & $\begin{array}{l}\text { Reference } \\
\text { standard }\end{array}$ & Country \\
\hline $\begin{array}{c}\text { Malhame } \\
\text { [37] }\end{array}$ & 2019 & $2007-2018$ & 60 & $32 \pm 6.8$ & Retrospective & $39(65 \%)$ & $\begin{array}{l}\text { Elevated } \\
\text { BNP level } \\
(<100 \mathrm{pg} / \\
\mathrm{mL})\end{array}$ & USA \\
\hline $\begin{array}{c}\text { Tanous } \\
{[48]}\end{array}$ & 2010 & 2006-2018 & 78 & $31 \pm 5$ & Prospective & $66(84 \%)$ & $\begin{array}{l}\text { Elevated } \\
\text { BNP level } \\
(>100 \mathrm{pg} / \\
\mathrm{mL})\end{array}$ & Canada \\
\hline KAN [51] & 2019 & $2016-2017$ & 60 & $27.15 \pm 2.2$ & Prospective & - & $\geq 500 \mathrm{ng} / \mathrm{L}$ & China \\
\hline Singh [52] & 2018 & - & 50 & $26.3 \pm 3.1$ & Prospective & $38(76 \%)$ & $\begin{array}{l}100-500 \mathrm{ng} / \\
\mathrm{L}\end{array}$ & India \\
\hline $\begin{array}{l}\text { Umazume } \\
\text { [53] }\end{array}$ & 2018 & 2014-2017 & 51 & $34.4 \pm 5.1$ & Prospective & - & $\begin{array}{l}\text { Elevated } \\
\text { BNP level } \\
(<100 \mathrm{pg} / \\
\mathrm{mL})\end{array}$ & Japan \\
\hline
\end{tabular}

SD Standard deviation

aforementioned criteria were directly reviewed by two of the authors, with disagreement resolved by discussion. If the diagreement remained unresolved, consensus was achieved by consultation with a third author. Minimum, maximum and median measures were applied and the mean and standard deviations (SD) were obtained. Additional data was carefully extracted using a standardized data collection form.

Publication Bias A quantitative analysis on total bias was performed using Stata version 14.0 (StataCorp, College Station, TX, USA) to draw funnel plots and perform Deek's test. An asymmetric distribution of data points in the funnel diagram, together with a significance value of $p<0.05$, indicated the existence of a potential publication bias [20].

Heterogeneity The Chi-square $\left(\chi^{2}\right)$ test was used to evaluate the heterogeneity in calculating the overall specificity and sensitivity. In addition, Cochran's Q test was used to investigate heterogeneity in diagnostic odds ratio (DOR) pooling. When the results of these qualitative tests revealed a $p$ value $<0.05$, we realized that there was a statistically significant heterogeneity. The $I^{2}$ test was also performed in each pooled analysis to quantitatively estimate the ratio of total changes throughout the study that could be attributed to heterogeneity versus chance. The value of $I^{2}$, expressed as a value in the range between 0 and $100 \%$, was $>50 \%$, indicating significant heterogeneity. The presence of a threshold effect is exhibited in the form of a curvilinear shape in summary receiver operating characteristic (SROC) curves.

\section{RESULTS}

Our search process identified 529 articles, of which 460 were excluded after review of the unrelated abstract and title. The full text of 69 articles was assessed, resulting in the exclusion 
of another 50 articles for the following reasons: studies with no full text available $(n=19)$; studies evaluating other populations $(n=8)$; reviews $(n=12)$; cross-review for included references; letter to editors $(n=3)$; and studies with no reported quality estimate [8] (Fig. 1). Ultimately, 13 unique studies were included in this review. In two of the included studies, data (111 participants) were reported at the threshold of $\leq 100 \mathrm{ng} / \mathrm{L}$, in two other studies (128 participants), the threshold was determined to be $100-500 \mathrm{ng} / \mathrm{L}$ and in one study (60 participants) data were reported at the threshold of $\geq 500 \mathrm{ng} / \mathrm{L}$ (Table 1). Three studies evaluated the diagnostic accuracy of NT-proBNP in diagnosing cardiac complications in pregnancy and six studies evaluated the association between NT-proBNP levels and development of pre-eclampsia. One study evaluated both cardiac complications and pre-eclampsia.

\section{Diagnostic Accuracy of BNP and NT- proBNP}

The overall sensitivity and specificity for BNP and NT-proBNP were 94 versus $78 \%$ and 75 versus $74 \%$, respectively. The corresponding rates for positive and negative predictive values were 80 versus $20.5 \%$ and 93 versus $97 \%$, respectively. In addition, the area under the curve for BNP and NT-proBNP was 0.96 and 83.5, respectively (Figs. 2, 3, 4) (Table 2). The high positive likelihood ratio (LR+; 3.95) and low rate of the negative LR (LR-; 0.091) of BNP was found to be associated with a lower the rate of misdiagnosis and a lower rate of missed diagnosis in the diagnostic test (Fig. 5). The pooled sensitivity, specificity, positive and negative predictive values of BNP within the level of $\leq 100 \mathrm{ng} / \mathrm{L}$ were calculated to be 0.95 (95\% confidence interval [CI] 0.86-0.99), 0.62 (95\% CI 0.48-0.74), 71\% and 91\%, respectively. The pooled sensitivity, specificity, positive predictive and negative predictive values of BNP

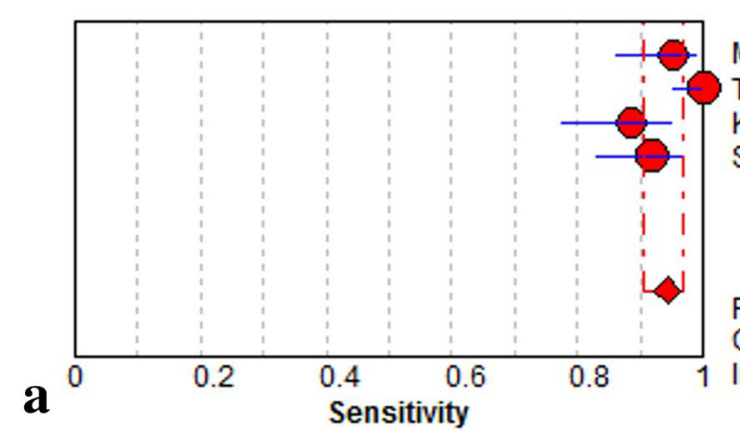

Malhame

Tanous

Kan

Singh

Pooled Sensitivity $=0.94(0.91$ to 0.97$)$

Chi-square $=13.01 ; \mathrm{df}=3(\mathrm{p}=0.0046)$

Inconsistency (I-square) $=76.9 \%$

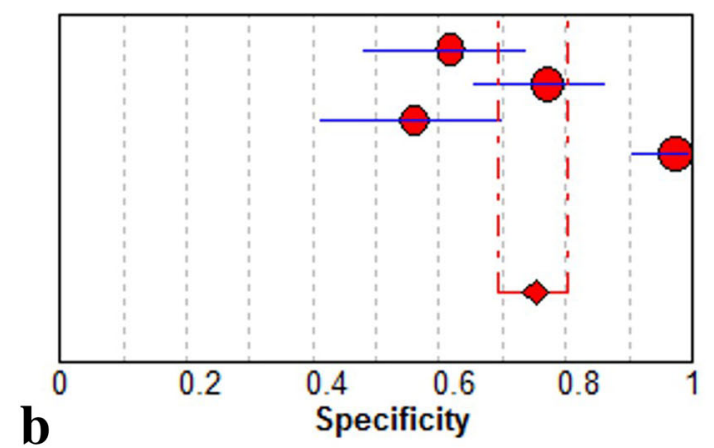

\section{Specificity $(95 \% \mathrm{Cl})$}

\section{Malhame}

Tanous

Kan

Singh

Pooled Specificity $=0.75(0.69$ to 0.80$)$

Chi-square $=42.44 ; \mathrm{df}=3(\mathrm{p}=0.0000)$

Inconsistency (l-square) $=92.9 \%$

Fig. 2 Sensitivity (a) and specificity (b) of B-Type Natriuretic Peptide in diagnosing cardiac complications in pregnancy 


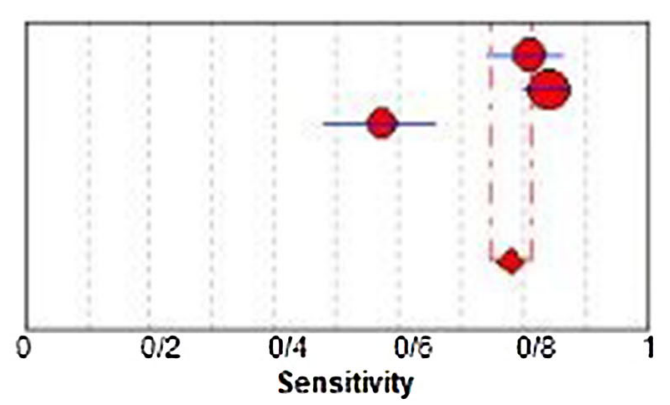

Kampman

Alvarez-Fermandez

Siegmund

Pooled Sensitivity $=0 / 78(0 / 75$ to $0 / 81)$

Chi-square $=36 / 17 ; d f=2(p=0 / 0000)$

Inconsistency (1-square $)=94 / 5 \%$

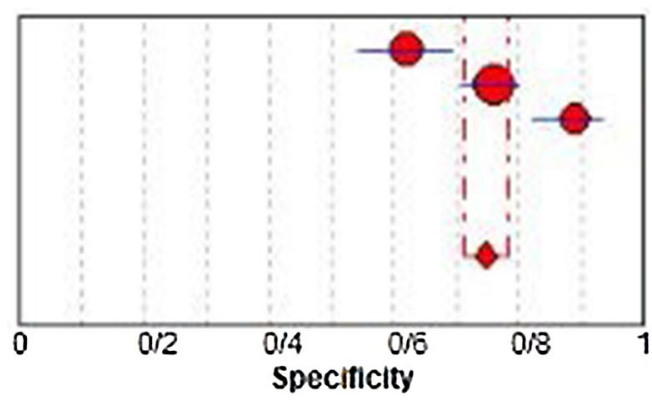

Sensitlvity $(95 \%$ Cl)

$0,81 \quad(0 / 74-0 / 87)$

$0 / 84 \quad(0 / 80-0 / 88)$

$0 / 57 \quad(0 / 48-0 / 66)$
Kampman

Alvarez-Fermandez

Slesmund

Pooled Specificity $=0 / 75(0 / 79100 / 78)$

Chi-square $=29 / 10: d f=2(p=0 / 0000)$

Inconsistency (l-square) $=93 / 1 \%$

Fig. 3 Sensitivity (a) and specificity (b) of NT-proBNP in diagnosing cardiac complications in pregnancy

within the threshold of 100-500 ng/L were calculated to be 0.98 (95\% CI 0.90-0.99), 0.92 (95\% CI 0.83-0.95), 97\% and 92\%, respectively. Since only one study reported data for BNP at a threshold of $\geq 500 \mathrm{ng} / \mathrm{L}$, this interval could not be analyzed in our meta-analysis; however, the sensitivity was more likely to decrease as the threshold increased (Table 3).

\section{The Overall Mean NT-proBNP Levels}

The overall mean NT-proBNP value was calculated to be 272.6 among women who developed pre-eclamsia compared to 72.3 among healthy pregnant women (Table 4). All included studies reported a significant correlation between high levels of NT-proBNP and the development of pre-eclampsia.

\section{Diagnostic Accuracy of BNP According to Country}

The best overall sensitivity of BNP for diagnosing cardiac complications during pregnancy was reported by Canadian authors (100\%), while the least sensitivity was reported in a study from China (88\%). Specificity was the best in an Indian study (92\%). However, an American study reported a specificity of $62 \%$ (Fig. 6).

\section{DISCUSSION}

The aim of this systematic review and metaanalysis was to examine the diagnostic accuracy of different BNP levels in the evaluation of pregnant and recently-delivered women with suspected cardiac failure. Women with cardiac disorders have higher BNP levels during their pregnancy compared to their non-pregnant counterparts, which may indicate an incomplete adaptation to the hemodynamic load of pregnancy. Pregnancy and physical exercise have a number of common characteristics in terms of hemodynamic alterations. Higher levels of BNP in non-pregnant women with underlying cardiac disease can be associated with some forms of latent ventricular dysfunction. However, this increase might only occur during physical exercise [21, 22], with the higher levels of BNP possibly indicative of 


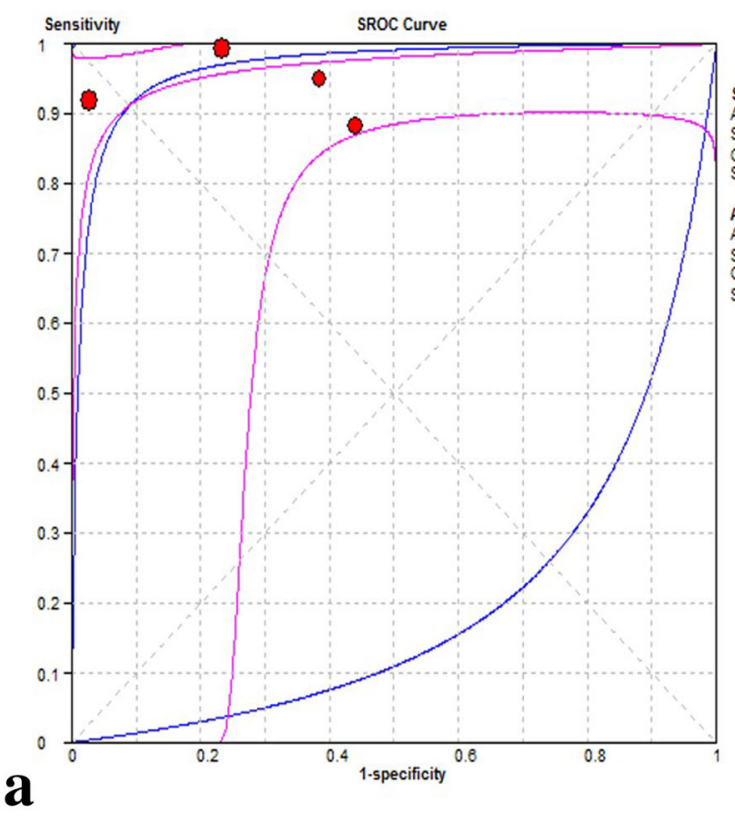

a

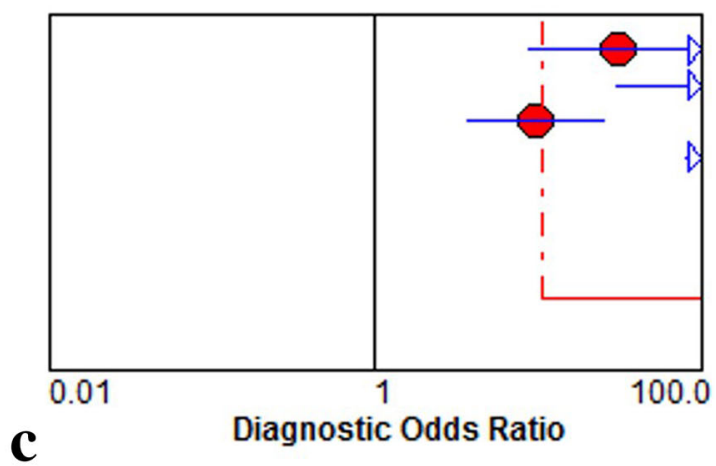

Malhame

Tanous

Kan

Singh

Random Effects Model

Pooled Diagnostic Odds Ratio $=71.45$ (10.47 to 487.57)

Cochran- $Q=19.84 ; \mathrm{df}=3(\mathrm{p}=0.0002)$

Inconsistency $($ l-square $)=84.9 \%$

Tau-squared $=3.0916$
Fig. 4 Summary receiver (SROC) curve for B-Type natriuretic peptide in diagnosing Cardiac Complications in pregnancy (a). Fagan's nomogram for the calculation of post-test probabilities. A pre-test probability of $50 \%$ for diagnostic tool was fixed, which was estimated by the

subclinical disorders that present only with physical stress $[23,24]$. This increase is paralleled by the increase in the mass of the left ventricular $(\mathrm{LV})$ wall and the dimensions of the LV chamber [25, 26]. However, healthy women can generally compensate for the increased volume that occurs during pregnancy and have stable levels of BNP during their pregnancy $[27,28]$. Increased levels of BNP during pregnancy, a physiological state that is associated number of symptomatic cases in selected studies. BNP had a post-test probability of $69.4 \%(\mathbf{b})$. Diagnostic odds ratio for B- natriuretic peptide in diagnosing Cardiac Complications in pregnancy $(\mathbf{C})$

with volume overload and subsequent ventricular dilatation, can to some extent explain the mechanism which causes clinical deterioration. There is some evidence suggesting that pregnancy has a detrimental effect on the normal course of the cardiac disorder in women with LV systolic function [29] and may subsequently affect the performance of ventricles [30, 31]. Five related studies were included in this metaanalysis. Although these results were not 


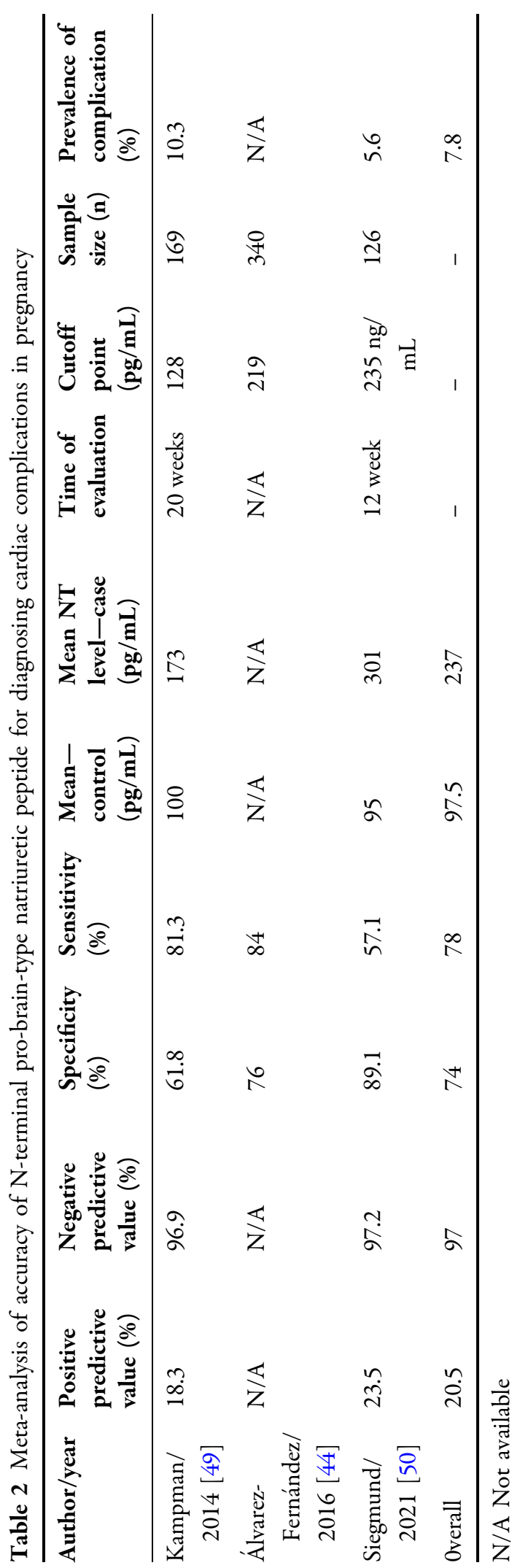

consistent across all of the pooled results, the diagnostic performance of BNP in diagnosing cardiac complications showed a pooled sensitivity of $94 \%$ (95\% CI of $0.91-0.97)$ and a pooled specificity of $75 \%$ (95\% CI $0.69-0.80)$, as well as an AUC ( \pm SD) value of $0.7991 \pm 0.0164$. The sensitivity of BNP in detecting heart failure in the general population has been reported to be about 0.70 , indicating the potential capacity of BNP to be used to diagnose heart failure [32].

The results of this systematic review and meta-analysis are comparable to those of other studies on non-pregnant populations [33, 34]. In the landmark study "Breathing Not Properly", which evaluated BNP in patients presenting with acute dyspnea, the authors stated that BNP levels at a cutoff value of $100 \mathrm{pg} / \mathrm{mL}$ had a sensitivity of $90 \%$ (95\% CI of $88-92)$ and an accuracy of $83 \%$ [33]. Therefore, when BNP was employed in the obstetric population, it was at least at the same levels of sensitivity and accuracy as in the non-pregnant population. Although the baseline levels of BNP were higher among pregnant and newly-delivered women $[23,35,36]$, the cutoff values of BNP appeared to be relatively similar to those used in the nonpregnant population [33]. Thus, measuring the level of BNP might improve decision-making in terms of best management of the patient. Clinicians can test the level of BNP to detect the physiological signs of pregnancy along with early signs of cardiac failure. Assuming a $94 \%$ sensitivity and a 0.091 negative LR, a negative BNP test can be used to help prevent heart failure. Malhamé et al. argued that, assuming a positive LR of $>2$ for BNP, a positive test may indicate the need for additional cardiac imaging [37]. The positive LR in this meta-analysis was calculated to be 3.95 . The safest cutoff value used, in light of the findings of Malhamé et al., was $78 \mathrm{pg} / \mathrm{mL}$, which can maximize sensitivity at the cost of lowering specificity.

Our results indicate a partially better sensitivity and specificity for BNP in comparison with NT-proBNP, which is consistent with the results reported by Hill et al. who compared the diagnostic accuracy of these biomarkers for the diagnosis of heart failure in the emergency department [37]. Some of the included studies 

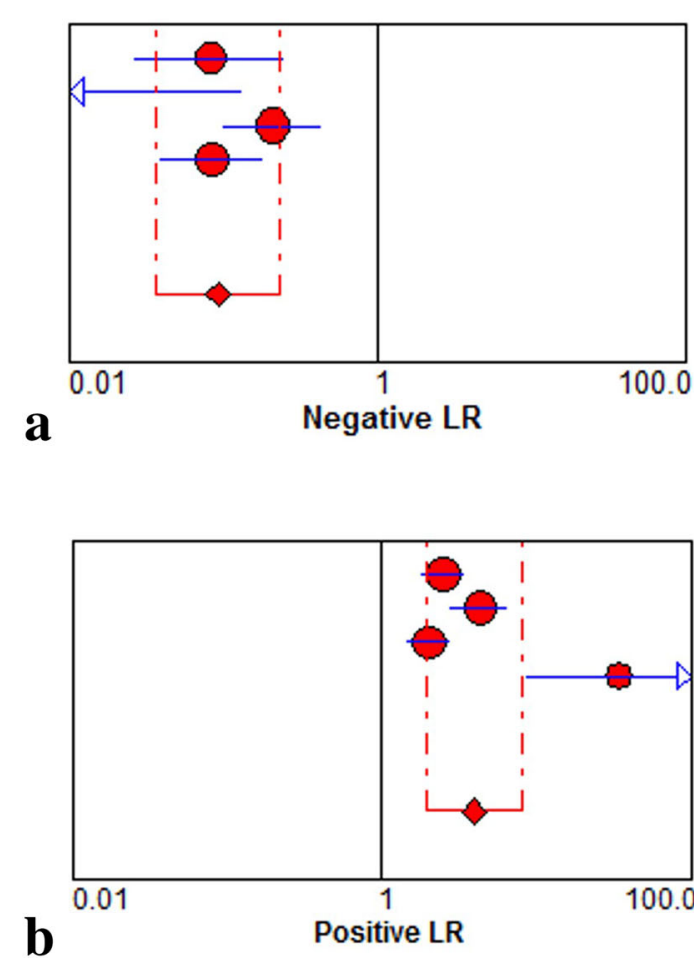

Negative LR $(95 \% \mathrm{Cl})$

Malhame $\quad 0.08 \quad(0.03-0.25)$

Tanous $\quad 0.01 \quad(0.00-0.13)$

Kan $\quad 0.21 \quad(0.10-0.44)$

Singh $\quad 0.08 \quad(0.04-0.18)$

Random Effects Model

Pooled Negative $L R=0.09$ (0.04 to 0.23 )

Cochran $-Q=9.01 ; \mathrm{df}=3(\mathrm{p}=0.0292)$

Inconsistency (l-square) $=66.7 \%$

Tau-squared $=0.5375$

\section{Positive LR $(95 \% \mathrm{Cl})$}

Malhame $\quad 2.48(1.79-3.43)$

Tanous $\quad 4.28(2.80-6.53)$

Kan $\quad 2.01(1.45-2.78)$

Singh $\quad 34.00 \quad(8.65-133.63)$

Random Effects Model

Pooled Positive LR $=3.96$ ( 1.94 to 8.06 )

Cochran- $Q=30.30 ; d f=3(p=0.0000)$

Inconsistency (l-square) $=90.1 \%$

Tau-squared $=0.4289$

Fig. 5 Negative LR (a) and positive LR (b) of B-Type Natriuretic Peptide in diagnosing cardiac complications in pregnancy

Table 3 Meta-analysis of accuracy of brain-type natriuretic peptide in diagnosing cardiac complications in pregnancy

\begin{tabular}{|c|c|c|c|c|c|}
\hline Parameter & All $(95 \% \mathrm{CI})$ & $\begin{array}{l}\text { cutoff } \leq 100 \mathrm{ng} / \mathrm{L} \\
(95 \% \mathrm{CI})\end{array}$ & $\begin{array}{l}\text { cutoff } 100-500 \mathrm{ng} / \mathrm{L} \\
(95 \% \mathrm{CI})\end{array}$ & $\begin{array}{l}\geq 500 \mathrm{ng} / \mathrm{L} \\
(95 \% \mathrm{CI})\end{array}$ & $\begin{array}{l}\text { Prospective }(95 \% \\
\text { CI) }\end{array}$ \\
\hline $\begin{array}{l}\text { Sensitivity }(95 \% \\
\text { CI) }\end{array}$ & $\begin{array}{l}94 \% \\
\quad(0.91-0.97)\end{array}$ & $95 \%(0.86-0.99)$ & $92 \%(0.83-0.95)$ & $88 \%(0.77-0.95)$ & $94 \%(0.89-0.96)$ \\
\hline $\begin{array}{l}\text { Specificity }(95 \% \\
\text { CI) }\end{array}$ & $\begin{array}{l}75 \% \\
\quad(0.69-0.80)\end{array}$ & $62 \%(0.48-0.74)$ & $98 \%(0.90-0.99)$ & $63 \%(0.50-0.76)$ & $80 \%(0.74-0.850$ \\
\hline $\operatorname{PLR}(95 \% \mathrm{CI})$ & $\begin{array}{l}3.95 \\
\quad(1.94-8.06)\end{array}$ & $2.47(1.78-3.43)$ & $34.0(8.65-133.63)$ & $2.40(1.70-3.40)$ & $5.63(1.96-16.17)$ \\
\hline NLR (95\% CI) & $\begin{array}{l}0.09 \\
\quad 1(0.036-0.23)\end{array}$ & $0.081(0.026-0.249)$ & $0.08(0.03-133.63)$ & $0.18(0.08-0.37)$ & $8 \%(0.02-0.28)$ \\
\hline DOR (95\% CI) & $\begin{array}{l}71.44 \\
\quad(10.46-487.5)\end{array}$ & $30.56(8.56-109.09)$ & $408.00(79.59-2091.3)$ & $\begin{array}{l}13.07 \\
\quad(5.07-33.71)\end{array}$ & $\begin{array}{l}120.21 \\
\quad(7.26-1990)\end{array}$ \\
\hline PPV & $80 \%$ & $71 \%$ & $97 \%$ & $71 \%$ & $83 \%$ \\
\hline NPV & $93 \%$ & $92 \%$ & $92 \%$ & $84 \%$ & $93 \%$ \\
\hline Accuracy & $85 \%$ & $78.3 \%$ & $94 \%$ & $76 \%$ & $87 \%$ \\
\hline AUC-SROC & 0.9842 & 0.9845 & 0.9867 & 0.9819 & 0.9854 \\
\hline$I^{2}$ & $76.9 \%$ & $84.1 \%$ & $85.6 \%$ & $94 \%$ & $81 \%$ \\
\hline
\end{tabular}

AUC-SROC Area under the curve-summary receiver operating characteristic curve, $C I$ confidence interval, DOR diagnostic odds ratio, $N L R$ negative likelihood ratio, NPV negative predictive value, $P L R$ positivie likelihood ratio, $P P V$ positive predictive value 
Table 4 Meta-analysis of mean levels of $\mathrm{N}$-terminal pro-brain-type natriuretic peptide in association with pre-eclampsia

\begin{tabular}{llll}
\hline First author/year of publication & Sample size $(\boldsymbol{n})$ & Mean-case $(\mathbf{p g} / \mathbf{m L})$ & Mean-control $(\mathbf{p g} / \mathbf{m L})$ \\
\hline Hafiz/2021 [42] & 60 & $673.50 \pm 486.86$ & $262.75 \pm 457.04$ \\
Moghbeli/2010 [43] & 63 & 197 & 58 \\
Fernández/2016 [44] & 340 & 169 & 34 \\
Junus/2014 [45] & 74 & 365 & 48 \\
Giannubilo/2017 [46] & 98 & $121.2 \pm 26.3$ & $42.5 \pm 11.4$ \\
Bakacak/2015 [34] & 76 & 110 & 37 \\
Overal meanl & - & 272.6 & 80.3 \\
\hline
\end{tabular}

Values are presented as the mean $( \pm S D$ where available)

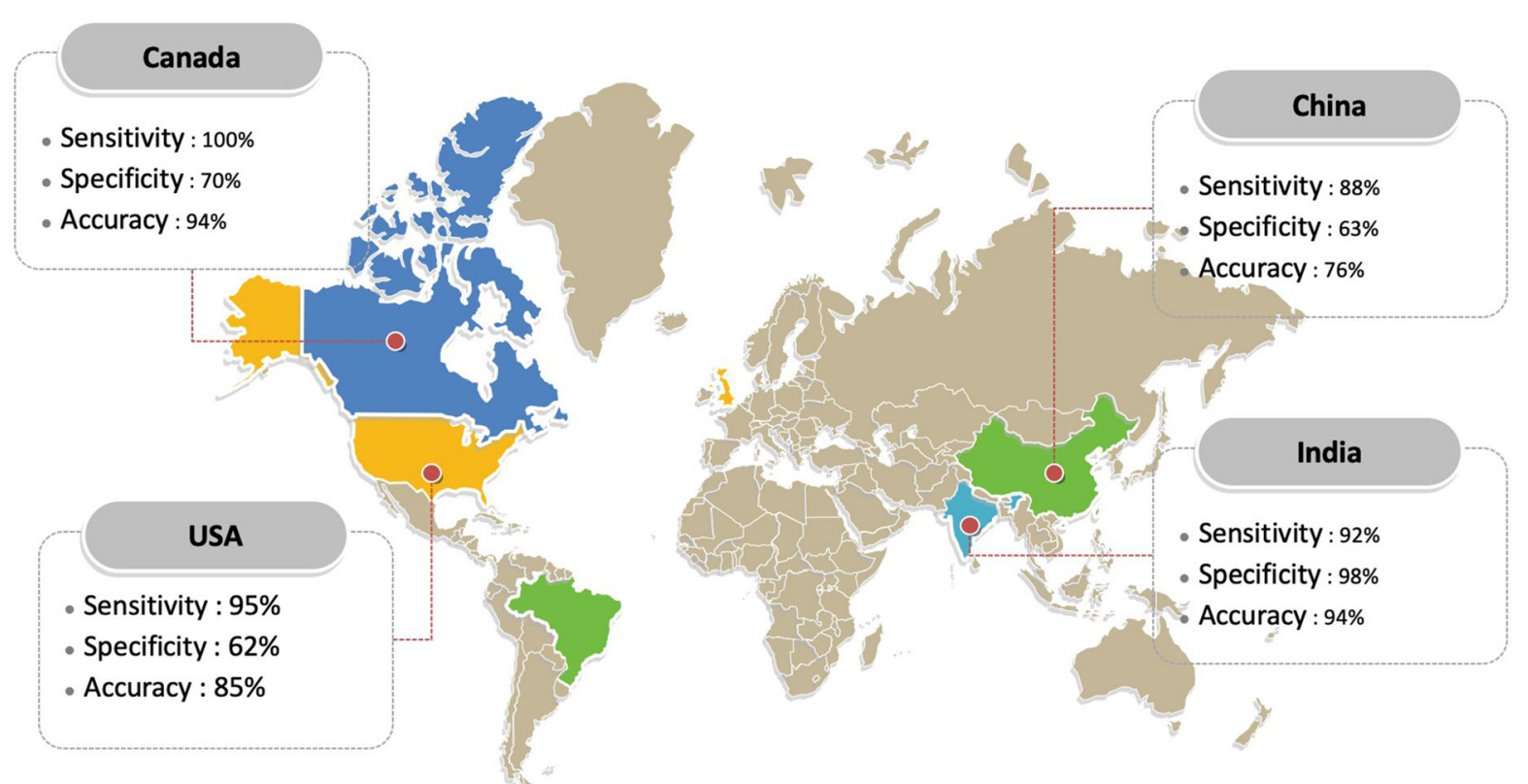

Fig. 6 Pooled sensitivity, specificity and accuracy for B-Type Natriuretic Peptide in diagnosing cardiac complications in pregnancy

indicated that when interpreting BNP levels in patients with pre-eclampsia, it is important to consider that BNP levels can be increased by hypertension, even if there are no signs of cardiac failure $[23,34,39$, 40]. However, it has been suggested that the increase in BNP level is clinically dependent on the degree of clinical and non-clinically detectable ventricular abnormalities and the inherited state of preeclampsia [34, 38]. All of our included studies which evaluated NT-proBNP levels reported a significant correlation between the levels of this biomarker and the development of preeclampsia [42-47].

Tanous et al. found levels of BNP indicative of cardiac failure in $38 \%$ of pregnant women with underlying cardiac conditions [48]. These authors also reported that many of these women presented no signs of cardiac decompensation. Despite being inconclusive, this 
reaction might be a sign of limited cardiac reserve. In addition, the levels of BNP were higher in pregnant patients with underlying cardiac disease than the healthy women. However, there was no significant difference between these levels in patients with and without clinical events [48]. These results indicate that these women, especially those who have elevated levels of BNP during their pregnancy, should maintain post-pregnancy care. Early detection of deterioration in such conditions, before any acute events occur, is of great importance in patients with underlying cardiac conditions, since both the mother and fetus will be endangered by acute conditions and the options for treating the patient can be limited due to pregnancy status. As early diagnosis is highly critical in such cases, studies have focused on risk stratification through prenatal and clinical echocardiographic variables $[41,42]$. However, few studies have evaluated the application of biomarkers or other measurements capable of determining the adaptability of the heart with the hemodynamic load of pregnancy.

There are several limitations to our study which need to be addressed. First, as there were an insufficient number of studies that evaluated the diagnostic accuracy of both BNP and NT-pro BNP in the same population, we had to include different studies with different samples, which could cause heterogenicity. Secondly, only three studies evaluated NT-proBNP, and each of these considered a different cutoff value which affected the accuracy of our pooled measurements. Thirdly, the studies investigating preeclampsia did not provide any data on the diagnostic accuracy of NT-proBNP and only reported the mean values.

\section{CONCLUSION}

In summary, the results of our study suggest that BNP as well as NT-proBNP levels can be used as a diagnostic tool among pregnant and newly-delivered women to diagnose cardiac complications, including heart failure and preeclampsia. BNP showed a relatively better diagnostc accuracy than NT-proBNP, but it should be considered that the number of included studies evaluating NT-pro-BNP was low and the studies were inconsistent in terms of cutoff value. Further studies are required to confirm the prospective use of BNP and NT-proBNP for assessing common symptoms that indicate cardiac complications during labor. Moreover, the clinical use of the NT-proBNP test in this field requires further study.

\section{ACKNOWLEDGEMENTS}

Compliance with Ethics Guidelines. This article is based on previously conducted studies and does not contain any new studies with human participants or animals performed by any of the authors.

Data Availability. The datasets generated during and/or analyzed during the current study are available from the corresponding author on reasonable request.

Disclosures. Mahboobeh Sheikh, Pouya Ostadrahimi, Morteza Salarzaei and Fateme Parooie have nothing to disclose.

Funding. No funding or sponsorship was received for this study or publication of this article.

Authorship. All named authors meet the International Committee of Medical Journal Editors (ICMJE) criteria for authorship for this article, take responsibility for the integrity of the work as a whole, and have given their approval for this version to be published.

Author Contributions. MSH and POR participated in the conception and design of the study, library searches and assembling relevant literature, critical review of the paper, supervising writing of the paper and database management. MS and FP participated in data collection, library searches and assembling relevant literature, writing the paper and critical review of the paper. 
Open Access. This article is licensed under a Creative Commons Attribution-NonCommercial 4.0 International License, which permits any non-commercial use, sharing, adaptation, distribution and reproduction in any medium or format, as long as you give appropriate credit to the original author(s) and the source, provide a link to the Creative Commons licence, and indicate if changes were made. The images or other third party material in this article are included in the article's Creative Commons licence, unless indicated otherwise in a credit line to the material. If material is not included in the article's Creative Commons licence and your intended use is not permitted by statutory regulation or exceeds the permitted use, you will need to obtain permission directly from the copyright holder. To view a copy of this licence, visit http://creativecommons.org/licenses/by$\mathrm{nc} / 4.0 /$.

\section{REFERENCES}

1. Berger R, Huelsman M, Strecker K, et al. B-type natriuretic peptide predicts sudden death in patients with chronic heart failure. Circulation. 2002;105:2392-7.

2. de Lemos JA, Morrow DA, Bentley JH, et al. The prognostic value of B-type natriuretic peptide in patients with acute coronary syndromes. N Engl J Med. 2001;345:1014-21.

3. Wazni OM, Martin DO, Marrouche NF, et al. Plasma B-type natriuretic peptide levels predict postoperative atrial fibrillation in patients undergoing cardiac surgery. Circulation. 2004;110:124-7.

4. Leuchte HH, Holzapfel M, Baumgartner RA, Neurohr C, Vogeser M, Behr J. Characterization of brain natriuretic peptide in long-term follow-up of pulmonary arterial hypertension. Chest. 2005;128: 2368-74.

5. Sacher F, Corcuff J-B, Schraub P, et al. Chronic atrial fibrillation ablation impact on endocrine and mechanical cardiac functions. Eur Heart J. 2008;29: 1290-5.

6. Bernus A, Wagner BD, Accurso F, Doran A, Kaess H, Ivy DD. Brain natriuretic peptide levels in managing pediatric patients with pulmonary arterial hypertension. Chest. 2009;135:745-51.
7. Siu SC, Sermer M, Colman JM, et al. Prospective multicenter study of pregnancy outcomes in women with heart disease. Circulation. 2001;104: $515-21$.

8. Khairy P, Ouyang DW, Fernandes SM, Lee-Parritz A, Economy KE, Landzberg MJ. Pregnancy outcomes in women with congenital heart disease. Circulation. 2006;113:517-24.

9. Adams KF Jr, Giblin EM, Pearce N, Patterson JH. Integrating new pharmacologic agents into heart failure care: Role of heart failure practice guidelines in meeting this challenge. Pharmacotherapy. 2017;37:645-56.

10. McMurray JJ, Adamopoulos S, Anker SD, et al. ESC Guidelines for the diagnosis and treatment of acute and chronic heart failure 2012: The Task Force for the Diagnosis and Treatment of Acute and Chronic Heart Failure 2012 of the European Society of Cardiology. Developed in collaboration with the Heart Failure Association (HFA) of the ESC. Eur J Heart Fail 2012;14: 803-69

11. Vaught AJ, Kovell LC, Szymanski LM, et al. Acute cardiac effects of severe pre-eclampsia. J Am Coll Cardiol. 2018;72:1-11.

12. Chow SL, Maisel AS, Anand I, et al. Role of biomarkers for the prevention, assessment, and management of heart failure: a scientific statement from the American Heart Association. Circulation. 2017;135:e1054-91.

13. Maisel AS, Krishnaswamy P, Nowak RM, et al. Rapid measurement of B-type natriuretic peptide in the emergency diagnosis of heart failure. N Engl J Med. 2002;347:161-7.

14. Hameed AB, Chan K, Ghamsary M, Elkayam U. Longitudinal changes in the B-type natriuretic peptide levels in normal pregnancy and postpartum. Clin Cardiol. 2009;32:E60-2.

15. Resnik JL, Hong C, Resnik R, et al. Evaluation of B-type natriuretic peptide (BNP) levels in normal and preeclamptic women. Am J Obstet Gynecol. 2005;193:450-4.

16. Mayama M, Yoshihara M, Uno $K$, et al. Factors influencing brain natriuretic peptide levels in healthy pregnant women. Int J Cardiol. 2017;228: 749-53.

17. Borghi C, Esposti DD, Immordino V, et al. Relationship of systemic hemodynamics, left ventricular structure and function, and plasma natriuretic pep- tide concentrations during pregnancy complicated by pre-eclampsia. Am J Obstet Gynecol. 2000;183:140-7. 
18. Moher D, Liberati A, Tetzlaff J, et al. Preferred reporting items for systematic reviews and metaanalyses: the PRISMA statement. Int J Surg. 2010;8: 336-41.

19. Tricco AC, Lillie E, Zarin W, et al. PRISMA extension for scoping reviews (PRISMA-ScR): checklist and explanation. Ann Intern Med. 2018;169(7):467-73.

20. Deeks JJ, Macaskill P, Irwig L. The performance of tests of publication bias and other sample size effects in systematic reviews of diagnostic test accuracy was assessed. J Clin Epidemiol. 2005;58: 882-93.

21. Borghi C, Esposti DD, Immordino V, et al. Relationship of systemic hemodynamics, left ventricular structure and function, and plasma natriuretic peptide concentrations during pregnancy complicated by preeclampsia. Am J Obstet Gynecol. 2000;183:140-7.

22. Itoh H, Sagawa N, Mori T, Mukoyama M, Nakao K, Imura H. Plasma brain natriuretic peptide level in pregnant women with pregnancy-induced hypertension. Obstet Gynecol. 1993;82:71-7.

23. Resnik JL, Hong C, Resnik R, et al. Evaluation of B-type natriuretic peptide (BNP) levels in normal and preeclamptic women. Am J Obstet Gynecol. 2005; 193:450-4.

24. Grunewald C, Nisell H, Carlstrom K, Kublickas M, Randmaa I, Nylund L. Acute volume expansion in normal pregnancy and pre-eclampsia. Effects on plasma atrial natriuretic peptide (ANP) and cyclic guanosine monophosphate (cGMP) concentrations and feto- maternal circulation. Acta Obstet Gynecol Scand. 1994;73:294-9.

25. Ozcan T, Senoz S, Sahin N, Direm B, Gokmen O. Change in atrial natriuretic peptide concentration after acute plasma volume expansion in normal pregnancy and preeclampsia. Gynecol Obstet Invest. 1995;39:229-33.

26. Grewal J, Siu SC, Ross H, et al. Pregnancy outcomes in women with dilated cardiomyopathy. J Am Coll Cardiol. 2010;55:45-52.

27. Maisel AS, Krishnaswamy P, Nowak RM, et al. Rapid measurement of B-type natriuretic pep- tide in the emergency diagnosis of heart failure. N Engl J Med. 2002;347:161-7.

28. Itoh H, Sagawa N, Mori T, Mukoyama M, Nakao K, Imura H. Plasma brain natriuretic peptide level in pregnant women with pregnancy-induced hypertension. Obstet Gynecol. 1993;82:71-7.

29. Uebing A, Arvanitis P, Li W, et al. Effect of pregnancy on clinical status and ventricular function in women with heart disease. Int J Cardiol. 2010;139: $50-9$.

30. Guedes A, Mercier LA, Leduc L, Berube L, Marcotte F, Dore A. Impact of pregnancy on the systemic right ventricle after aMustard operation for transposition of the great arteries. J Am Coll Cardiol. $2004 ; 44: 433-7$.

31. Siu SC, Sermer M, Colman JM, et al. Prospective multicenter study of pregnancy outcomes in women with heart disease. Circulation. 2001;104: 515-21.

32. Ishii $\mathrm{H}$, Harada $\mathrm{K}$, Toyono $\mathrm{M}$, Tamura M, Takada G. Usefulness of exercise-induced changes in plasma levels of brain natriuretic peptide in predicting right ventricular contractile reserve after repair of tetralogy of Fallot. Am J Cardiol. 2005;95:1338-43.

33. Maisel AS, Krishnaswamy P, Nowak RM, et al. Rapid measurement of B-type natriuretic pep- tide in the emergency diagnosis of heart failure. N Engl J Med. 2002;347:161-7.

34. Bakacak M, Serin S, Ercan O, Kostu B, Bakacak Z, Kiran H. Association of serum N-terminal pro-brain natriuretic peptide levels with the severity of preeclampsia. J Matern Fetal Neonat Med. 2016;29: 2802-6.

35. Hameed AB, Chan K, Ghamsary M, Elkayam U. Longitudinal changes in the B-type natriuretic peptide levels in normal pregnancy and postpartum. Clin Cardiol. 2009;32:E60-2.

36. Mayama M, Yoshihara M, Uno K, et al. Factors influencing brain natriuretic peptide levels in healthy pregnant women. Int J Cardiol. 2017;228: 749-53.

37. Malhamé I, Hurlburt H, Larson L, Poppas A, Nau C, Bourjeily G, Mehta N. Sensitivity and specificity of B-type natriuretic peptide in diagnosing heart failure in pregnancy. Obstet Gynecol. 2019;134(3): 440-9.

38. Hill SA, Booth RA, Santaguida PL, Don-Wauchope A, Brown JA, Oremus M, Ali U, Bustamam A, Sohel $\mathrm{N}$, McKelvie R, Balion C. Use of BNP and NTproBNP for the diagnosis of heart failure in the emergency department: a systematic review of the evidence. Heart Failure Rev. 2014;19(4):421-38.

39. Prasad CS, Kumar S, Sumathy S, Kunjukutty R, Puthenveettil N, Sen AC, Sivabalakrishnan JB, Kumar RK. Pregnancy and pulmonary arterial hypertension-improving surveillance and outcomes with multidisciplinary care and $\mathrm{N}$ terminal pro-brain natriuretic peptide trends. J Maternal-Fetal Neonatal Med. 2020;16:1-7. 
40. Siu SC, Sermer M, Colman JM, et al. Prospective multicenter study of pregnancy outcomes in women with heart disease. Circulation. 2001;104: 515-21.

41. Ishii H, Harada K, Toyono M, Tamura M, Takada G. Usefulness of exercise-induced changes in plasma levels of brain natriuretic peptide in predicting right ventricular contractile reserve after repair of tetralogy of Fallot. Am J Cardiol. 2005;95:1338-43.

42. Khairy P, Ouyang DW, Fernandes SM, Lee-Parritz A, Economy KE, Landzberg MJ. Pregnancy outcomes in women with congenital heart disease. Circulation. 2006;113:517-24.

43. Hafiz A, Dewantiningrum J, Kristanto H, Pramono MB. Serum N-Terminal Pro B-Type Natriuretic Peptide is associated with maternal complication in pregnancy with severe preeclampsia.

44. Moghbeli N, Srinivas SK, Bastek J, Lu Y, Putt ME, Cappola TP, Elovitz MA. N-terminal pro-brain natriuretic peptide as a biomarker for hypertensive disorders of pregnancy. Am J Perinatol. 2010;27(04):313-9.

45. Álvarez-Fernández I, Prieto B, Rodríguez V, Ruano Y, Escudero AI, Álvarez FV. N-terminal pro B-type natriuretic peptide and angiogenic biomarkers in the prognosis of adverse outcomes in women with suspected preeclampsia. Clin Chim Acta. 2016;463: $150-7$.

46. Junus K, Wikström AK, Larsson A, Olovsson M. Placental expression of proBNP/NT-proBNP and plasma levels of NT-proBNP in early-and late-onset preeclampsia. Am Jo Hypertens. 2014;27(9): $1225-30$

47. Giannubilo SR, Pasculli A, Tidu E, Biagini A, Boscarato V, Ciavattini A. Relationship between maternal hemodynamics and plasma natriuretic peptide concentrations during pregnancy complicated by preeclampsia and fetal growth restriction. J Perinatol. 2017;37(5):484-7.

48. Tanous D, Siu SC, Mason J, Greutmann M, Wald RM, Parker JD, Sermer M, Colman JM, Silversides CK. B-type natriuretic peptide in pregnant women with heart disease. J Am Coll Cardiol. 2010;56(15): 1247-53.

49. Kampman MA, Balci A, van Veldhuisen DJ, et al. N-terminal pro-B-type natriuretic peptide predicts cardiovascular complications in pregnant women with congenital heart disease. Eur Heart J. 2014;35(11):708-15.

50. Siegmund AS, Pieper PG, Bouma BJ, Rosenberg FM, Groen H, Bilardo CM, van Veldhuisen DJ, Dickinson MG. Early N-terminal pro-B-type natriuretic peptide is associated with cardiac complications and function during pregnancy in congenital heart disease. Netherlands Heart J. 2021;29(5):262-72.

51. Kan C, Cao J, Hou J, Jing X, Zhu Y, Zhang J, Guo Y, Chen X. Correlation of miR-21 and BNP with pregnancy-induced hypertension complicated with heart failure and the diagnostic value. Exp Ther Med. 2019;17(4):3129-35.

52. Singh K, Sikka P, Suri V, Prasad R, Khullar M, Vijayvergiya R. Brain natriuretic peptide in pregnant women with heart disease. Obstet Med. 2020;13(1):25-9.

53. Umazume $\mathrm{T}$, Yamada $\mathrm{T}$, Yamada $\mathrm{S}$, Ishikawa $\mathrm{S}$, Furuta I, Iwano H, Murai D, Hayashi T, Okada K, Morikawa M, Yamada T. Morphofunctional cardiac changes in pregnant women: associations with biomarkers. Open Heart. 2018;5(2). 